\title{
Soil protection and the right to food: Sustainability implications for global climate governance and world agricultural trade?
}

\author{
Oliver C. Ruppel
}

Especially in Africa we know that scarce land is more than a source of food security, income and shelter. It is also subject to distributive inequalities, often related to cultural identity. It is thus often a source of political and economic competition, tribal and social tension as well as historical, feudal, imperial, missionary or colonial injustices. ${ }^{1}$

Indeed, the most significant natural capital asset is productive land and fertile soils. For those communities that rely heavily on land as their main source, especially the rural poor, human well-being and sustainable livelihoods are completely dependent upon and intricately linked to the health and productivity of the land.

Land is territory, property, a resource, our heritage, and much more. Land has economic, social and environmental value and, even when privately owned, it provides many benefits to society. ${ }^{2}$

While Africa's population is expected to double by 2050 the global population is projected to increase by a further $25 \%$ by the same year, approaching 10 billion people, which will substantially increase the demand for food and other agricultural products. Access to food is the right of every person, individually or in community with others. This right involves having physical and economic access at all times to sufficient, adequate and culturally acceptable food that is produced and consumed sustainably, so as to preserve access to food for future generations. The normative content of the right to food is linked to availability, accessibility, adequacy and sustainability - all of which must be built into legal entitlements and secured through accountability mechanisms. ${ }^{3}$

Soils are essential ecosystems that deliver valuable services such as the provision of food and carbon sequestration, among others. Therefore, soil is crucial for fighting climate change, protecting human health, safeguarding biodiversity and ecosystems and ensuring food security. ${ }^{4}$

Conventional food and agricultural trade, as well as global value chains, may need to be reconsidered to ameliorate the concerns. Changes in global food systems and the

FAO (2020a).

Larbodière et al. (2020: 8).

Cf. with further references, De Schutter (2014: para. 2).

European Commission (2020). 
increased globalisation of the food supply means that populations worldwide are at risk of exposure to various food safety hazards. This can, among other things affect food security, national economies and international trade. ${ }^{5}$

\section{Soil and the right to food}

Soils are essential in ensuring food security and thus also the right to food. ${ }^{6}$ Strategies in support of the progressive realisation of the right to food seem to be very much in line with the recommendations of the Committee on Economic, Social and Cultural Rights in its general comment No. 12 on the right to adequate food (para. 21). ${ }^{7}$

According to Article 25(1) of the Universal Declaration of Human Rights (UDHR), everyone has the right to a standard of living adequate for the health and well-being of himself and of his family, including food, while Article 11 of International Covenant on Economic, Social and Cultural Rights (ICESCR) recognises the right of everyone to an adequate standard of living for himself and his family, including adequate food; as a fundamental right of everyone to be free from hunger.

Article 11(2) ICESCR in recognising the fundamental right of everyone to be free from hunger, compels Parties to take measures to (a) improve methods of production, conservation and distribution of food by making full use of technical and scientific knowledge, by disseminating knowledge of the principles of nutrition and by developing or reforming agrarian systems in such a way as to achieve the most efficient development and utilization of natural resources; (b) taking into account the problems of both food-importing and food-exporting countries, to ensure an equitable distribution of world food supplies in relation to need.

Similarly, Article 24(2)(c) of the Convention on the Rights of the Child (CRC) obliges Parties to take appropriate measures to combat disease and malnutrition, including within the framework of primary health care, through, inter alia, the provision of adequate nutritious foods, taking into consideration the dangers and risks of environmental pollution.

In addition to the international human rights framework, regional human rights treaties have been developed, such as the African Charter for Human and People's Rights (Banjul Charter). It has been ratified by most African states and is considered to provide implicit recognition to the right to food in its Articles 4 (right to life), 16 (right to health) and 22 (right to economic and social development), as interpreted by the African Commission on Human and People's Rights Principles and Guidelines on the implementation of Economic, Social and Cultural rights in the African Charter on Human

FAO (2020b).

European Commission (2020).

Cf. with further references De Schutter (2014: para. 40). 
and People's Rights and in the case law of the African Commission. The right to food is further expressly recognised in relation to women in Article 15 of the Protocol to the Banjul Charter on the Rights of Women in Africa. The vast majority of African countries have ratified these regional and relevant international human rights treaties. ${ }^{8}$

While states have the obligation to respect, protect and fulfill the human right to food, this obligation is complemented by the following principal non-legally binding instruments relating to the right to adequate food, namely the 1974 Universal Declaration on the Eradication of Hunger and Malnutrition; the 1996 Rome Declaration on World Food Security; and the 2004 Voluntary Guidelines to support the progressive realization of the right to adequate food in the context of national food security.

In addition, the 2015 Sustainable Development Goals (SDGs), provide a universally accepted framework to foster global collaboration with a strong emphasis on the rule of law and human rights. While Agenda 2030 is aimed at fostering and renewing multilateralism and international cooperation on the global but common challenges, the SDGs include economic and social development goals that potentially involve tradeoffs with environmental sustainability. One of society's most urgent challenges is to satisfy the rights of people to a 'good life', including adequate food and nutrition, while remaining within the planetary boundaries. In other words, we need to reconcile agriculture and the environment to "end hunger, achieve food security and improved nutrition and promote sustainable agriculture" (Zero Hunger, SDG 2) and also "protect, restore and promote sustainable use of terrestrial ecosystems, sustainably manage forests, combat desertification, and halt and reverse land degradation and halt biodiversity loss" (Life on Land, SDG 15). ${ }^{9}$

In terms of the right to food, the SDGs call for more sustainable production and consumption patterns and agricultural and food systems that protect natural resources (i.e., soil). Possible supply chain approaches, for example, intervene at the point of end consumption of such products, the production of which in distant, politically sovereign states causes sustainability risks.

The 2014 Malabo Declaration of the African Union on Accelerated Agricultural Growth and Transformation for Shared Prosperity and Improved Livelihoods is another set of goals for a targeted approach to achieve the agricultural vision for the continent which is shared prosperity and improved livelihoods. In the Declaration the signatories inter alia commit themselves in the pursuit of agriculture-led growth as a main strategy to achieve targets on food and nutrition security and shared prosperity; and especially to ending hunger in Africa and to halving poverty by the year 2025, 
through inclusive agricultural growth and transformation and by means of enhancing resilience of livelihoods and production systems to climate variability. ${ }^{10}$

\section{$3.1 \quad$ UNFCCC}

The 1992 the United Nations Framework Convention on Climate Change (UNFCCC) was adopted to regulate levels of greenhouse gas concentration in the atmosphere, so as to, inter alia, avoid the occurrence of climate change on a level that would compromise initiatives in food production. Article 2 of the UNFCCC defines the parties' ultimate objective as the stabilisation of greenhouse gas concentrations in the atmosphere at a level that would prevent dangerous anthropogenic interference with the climate system.

So far, international climate policy has mostly focused on emission sources and thus on the avoidance of greenhouse gas emissions, for example from the electricity sector, the production industry, transport, and land-use changes. This will, however, be increasingly complemented by the preservation and enhancement of emission sinks to remove carbon dioxide from the atmosphere. To achieve the global climate targets adopted by the UNFCCC, alternative mitigation methods, as for example through programmes for re- or afforestation and the restoration of ecosystems, become more and more relevant. Despite the fact that the combination of bioenergy and carbon capture and storage, increased carbon sequestration in soils, ${ }^{11}$ and the direct capture of $\mathrm{CO}_{2}$ from ambient air need to be further researched and are not yet at the stage of market maturity, the carbon removal approach has considerable potential, while soils are the world's second largest carbon sink after the oceans. ${ }^{12}$

The most potentially devastating impacts of industrial modes of agricultural production stem from their contribution to increased greenhouse gas emissions. Together, field-level practices represent approximately 15 per cent of total human-made greenhouse gas emissions, inter alia from the loss of soil organic carbon in croplands. ${ }^{13}$

10 Malabo Declaration on Accelerated Agricultural Growth and Transformation for Shared Prosperity and Improved Livelihoods Malabo, Equatorial Guinea, 26 June 2014, at https://au.int/sites/default/files/documents/31247-doc-malabo_declaration_2014_11_26.pdf, accessed 25 November 2020.

11 Soil carbon sequestration is the process of capturing atmospheric $\mathrm{CO}_{2}$ through changing land management practices to increase soil carbon content. Various land management practices promote soil carbon sequestration.

12 Geden \& Schenuit (2020: 5).

13 De Schutter (2014: para. 7). 


\subsection{Paris Agreement}

The 2015 Paris Agreement, as part of the UNFCCC regime, in its Preamble includes the explicit acknowledgement "that climate change is a common concern of humankind" and that "Parties should, when taking action to address climate change, respect, promote and consider their respective obligations on human rights". As such the agreement binds its parties regarding activities on their respective territories and under their control.

The Paris Agreement supplements the UNFCCC and the Kyoto Protocol of 1997 by incorporating existing elements of this regime. Both the UNFCCC and Kyoto Protocol adopted rules on reporting and accounting for emissions from land use, land use change and forestry (LULUCF). These rules determine how parties have to report LULUCF in their regular emission inventories, which under the Kyoto Protocol is also relevant for accounting whether parties meet their emission reduction targets. ${ }^{14}$

According to Article 2, the Paris Agreement's overarching objective is to keep the increase in global temperature well below $2^{\circ} \mathrm{C}$, or even $1.5^{\circ} \mathrm{C}$. Parties are required to prepare and present individual climate plans (Nationally Determined Contributions NDCs) every five years that set out how the party intends to contribute to the collective objectives. Under the Paris Agreement, the Principle of Common but Differentiated Responsibilities (CBDR) is an obligation for all parties when formulating their NDCs. This is the result of protracted negotiations about the role and impact of historic and present, and of relative and absolute, GHG producers. Although the Paris Agreement does not specify how to take the CBDR principle into account, principles of justice and equity help to improve the understanding of the normative implications of climate law under the Paris Agreement. While equity as a normative concept has a sense of fairness, justice plays an important role in legal-political decisions in relation to climate policy in particular and through differentiation in obligations. ${ }^{15} \mathrm{GHG}$ emissions have global, not merely national, effects, which on the basis of the need to contain the potential proliferation of trade distortions due to climate policies in terms of equity, may justify sanctioning the inaction by large GHG emitters, which can have a serious impact on local food production affected by global warming. ${ }^{16}$

Through the sustainable development mechanism in Article 6, the Paris Agreement allows the space to harness the lowest cost mitigation options worldwide. This may incentivise policymakers to enhance mitigation ambition by speeding up climate action. ${ }^{17}$ This implies that global climate policy development and the future of the carbon market also relate to mechanisms which support and encourage sustainable climate

14 Bodle et al. (2020: 17)

15 Lawrence \& Reder (2019).

16 Häberli (2018: 34).

17 Tänzler et al. (2019). 
policies in host countries as production-based accounting does not necessarily reflect a country's contribution to global emissions because globalisation and consumption can prompt emissions beyond borders.

By signing the Paris Agreement (and in particular Article 14 therein), parties agreed on long-term goals backed by national plans that are collectively reviewed in the global stocktake, which is key to increasing ambition. While the first planned stocktake is scheduled for 2023, it has already become apparent today that the improved accuracy of carbon stock estimates would allow for more targeted interventions and better monitoring of the NDCs - which has equal significance for the protection of soil in the context of agricultural production. ${ }^{18}$ Whereas the UNFCCC does not explicitly provide for specific trade measures, the Kyoto Protocol contains more detailed obligations related to the reduction of greenhouse gases and provides for trade-affecting techniques such as tax impositions on carbon dioxide emissions and the elimination of subsidies adversely affecting the objective of the UNFCCC.${ }^{19}$ In addition, the parties to the Paris Agreement explicitly recognise -

[...] the fundamental priority of safeguarding food security and ending hunger, and the particular vulnerabilities of food production systems to the adverse impacts of climate change;

while Article 2(1)(b) of the Paris Agreement provides for -

[in]creasing the ability to adapt to the adverse impacts of climate change and foster climate resilience and low greenhouse gas emissions development, in a manner that does not threaten food production $[\ldots]$.

Notwithstanding the legally neutral wording of Article 2(1) when read in isolation, achieving its purpose $-{ }^{20}$

$[\ldots]$ is mandatory not for any one state or group of states, of course; it is mandatory for the state parties collectively. This straightforward logical implication of the Paris Agreement does not seem to have been noticed before, despite its potentially profound consequences.

The Paris Agreement further requires parties to engage in adaptation planning and implementation that takes into account "vulnerable people, places and ecosystems" and builds "the resilience of socio-economic and ecological systems, including through economic diversification and sustainable management of natural resources". Of course, soil as well as land use, land degradation and sustainable land management are closely linked to climate change in terms of carbon capture and storage and the emissions from deforestation and agriculture. This is underlined by Article 4 of the Paris Agreement, which explicitly includes the target "to achieve a balance between anthropogenic emissions by sources and removals by sinks of greenhouse gases in the second

18 Interestingly, in its NDCs, the Republic of South Africa, states that policy instruments under development include regulatory standards and controls for specifically identified GHG pollutants and emitters; see https://www4.unfecc.int/sites/ndcstaging/PublishedDocuments/South\%20Africa\%20First/South\%20Africa.pdf, accessed 12 February 2021.

19 Ruppel (2018).

20 Zahar (2020). 
half of this century", although the Paris Agreement fails to explicitly mention 'soil', 'land' or 'agriculture'. As such, the Paris Agreement only indirectly addresses soil protection in the general context of climate change. And despite the importance of land use and soil management for climate change, the UNFCCC, the Kyoto Protocol and the Paris Agreement have not established a comprehensive regime with regard to landrelated climate change measures. ${ }^{21}$ Article 5(1) of the Paris Agreement obliges parties to take action to conserve and enhance, as appropriate, sinks and reservoirs of greenhouse gases as referred to in Article 4(1)(d) of the Convention. Yet, in fact, agriculture first appeared in the ongoing climate negotiations under the Koronivia joint work on agriculture programme at COP 23 in 2017:22

The decision officially acknowledges the significance of the agriculture sectors in adapting to and mitigating climate change. Countries agreed to work together to make sure that agricultural development ensures both increased food security in the face of climate change and a reduction in emissions. The joint work is expected to address six topics related to soils, nutrient use, water, livestock, methods for assessing adaptation, and the socio-economic and food security dimensions of climate change across the agricultural sectors.

In order to achieve the aforementioned, countries should take all appropriate measures according to their capabilities to progressively achieve the protection of the interests of all concerned. And when speaking of 'all concerned' in the context of global food security, this phrase is by no means an exaggeration. Much of the work to translate the Paris Agreement and the NDCs into concrete climate interventions in agriculture is in progress.

Food systems are responsible for $21-37 \%$ of global greenhouse gas emissions and a major driver of deforestation and land degradation, yet there is still widespread food insecurity and malnutrition. Managing the land sector (agriculture, forestry, wetlands, bioenergy) sustainably and holistically could contribute up to $30 \%$ of the global climate mitigation effort. ${ }^{23}$

In 2018, the Paris Agreement adopted a transparency framework which, inter alia, included rules for reporting on and accounting for land use and land-use change, which is expected to eventually replace the existing UNFCCC framework. This may open opportunities also to shape new rules complementing the UNFCCC's Koronivia joint work on agriculture.

A wide range of policy instruments is needed to strengthen the mutually supportive role of the Paris Agreement and other international agreements when it comes to the protection of soil. The AFOLU (agriculture, forestry, and other land use) sector plays an important role in the $1.5^{\circ} \mathrm{C}$ pathways and is, inter alia, responsible for food production. Changes in the AFOLU sector are driven by demand changes, efficiency of production, and policy assumptions. While demand for agricultural products and other land-based commodities is influenced by consumption patterns, including dietary

21 Bodle at al. (2020: 53).

22 See http://www.fao.org/climate-change/our-work/what-we-do/koronivia/en/, accessed 12 February 2021.

23 Palahí et al. (2020). 
preferences and food waste (affecting demand for food), policy assumptions relate to the level of land protection, the treatment of food waste, policy choices about the timing of mitigation action, the choice and preference of land-based mitigation options, and interactions with other sectors and trade. ${ }^{24}$

In the soil-land-climate interface, effective policy responses must include carbon pricing, emissions trading schemes (including net $\mathrm{CO}_{2}$ emissions from agriculture), carbon taxes, ${ }^{25}$ regulations limiting GHG emissions and air pollution, forest conservation (mix of land-sharing and land-sparing) through participation, incentives for ecosystem services and secure tenure, protecting the environment, microfinance, crop and livelihood insurance, agriculture extension services, agricultural production subsidies, low export tax and import tariff rates on agricultural goods, dietary awareness campaigns, taxes on and regulations to reduce food waste, improved shelf life, sugar/fat taxes, and instruments supporting sustainable land management (including payment for ecosystem services, land-use zoning, REDD+, standards and certification for sustainable biomass production practices, legal reforms on land ownership and access, legal aid, and legal education), as well as reframing these policies as entitlements for women and small agricultural producers. ${ }^{26}$ Similarly, border carbon adjustments can help level the playing field and prevent emissions leakage, ${ }^{27}$ which occurs when climate action in one region merely shifts emissions elsewhere. ${ }^{28}$

Such is, for instance, European Union (EU) soil policy action, based on Article 191 of the Treaty on the Functioning of the EU (TFEU), which requires Union policy to aim at preserving, protecting and improving the quality of the environment, protecting human health, a prudent and rational utilisation of natural resources, promoting measures at international level to deal with regional or worldwide environmental problems, and in particular combating climate change.

The EU considers improved soil protection fundamentally important due to (1) the transboundary impacts of soil degradation, such as $\mathrm{CO}_{2}$ emissions from soil organic

24 Rogelj et al. (2018).

25 Such was for example the Carbon Tax Act 15 of 2019, a relatively new addition to South Africa's legislative record, aiming to provide for the imposition of a tax on the carbon dioxide $\left(\mathrm{CO}_{2}\right)$ equivalent of greenhouse gas emissions; and to provide for matters connected therewith. This aim is expected to be achieved by the deployment of a range of measures to support the system of desired emissions reduction outcomes, including the appropriate pricing of carbon, the use of emissions offsets and economic incentives for rewarding the efficient use of energy to provide appropriate price signals to help nudge the economy towards a more sustainable growth path. Such tax phased in over time allows for learning, while the tax revenue can for example finance additional climate change mitigation efforts. Whether a carbon tax yields a better result, for global food security, than carbon sequestration, depends on many different factors. Taxation for climate change mitigation could be included under any broad (NDC) commitment to reduce emissions or in the promotion of green technologies.

26 Rogelj et al. (2018).

27 Peters et al. (2011).

28 Kasturi et al. (2019). 
carbon and loss of biodiversity, hampering EU food security through reduced production of food commodities traded in the internal market, hampering water quality across borders through contaminants and sediments in river basins, food safety concerns from soil contaminants; (2) the absence of a level playing field for economic operators subject to very different national soil protection regimes, leading to a distortion of the internal market; and (3) the risk that the EU and its Member States will fail to fulfil international and European commitments in the field of environment, sustainable development and climate. ${ }^{29}$

EU Member States have to ensure that greenhouse gas emissions from land use, land use change or forestry are offset by at least an equivalent removal of $\mathrm{CO}_{2}$ from the atmosphere in the period 2021 to 2030. The Regulation on the inclusion of greenhouse gas emissions and removals from land use, land use change and forestry (LULUCF) into the 2030 climate and energy framework was adopted by the Council on 14 May 2018, following the European Parliament vote on 17 April 2018. It is also in line with the Paris Agreement, which points to the critical role of the land use sector in reaching long-term climate mitigation objectives. ${ }^{30}$

Moreover, the EU Biodiversity Strategy for 2030 announced the update of the 2006 EU Soil Thematic Strategy to address soil and land degradation in a comprehensive way and to help achieve land degradation neutrality by 2030 . The Biodiversity Strategy for 2030 highlights that it is essential to step up efforts to protect soil fertility, reduce erosion and increase soil organic matter. The European Court of Auditors recommended to the European Commission to aim at a better understanding of land degradation and desertification in the EU, to assess the need to enhance the EU legal framework for soil, and to step up actions towards delivering EU and international commitments, and particularly land degradation neutrality by 2030. The European Parliament called on the EU and the Member States to make strong commitments towards sustainable food systems, agriculture and forestry, including requirements and strategies for the protection of soils. The European Environment Agency called for a comprehensive and coherent policy framework to protect land and soil. The strong political will and momentum guides the new EU soil strategy, which is already underway to consolidate, complement and steer action in the different policy areas that affect and depend on soil and guide the implementation of sustainable soil and land management practices. It is expected to cover key horizontal aspects from funding instruments to developing knowledge, research, communication and international cooperation. This will be done in close coordination and complementarity with other European Green Deal initiatives, including the upcoming Zero Pollution Action Plan, and other initiatives resulting from the EU Biodiversity Strategy for 2030 and the Farm to Fork Strategy. This also includes the legally binding EU nature restoration targets that the

29 European Commission (2020).

30 Cf. https://ec.europa.eu/clima/policies/forests/lulucf_en, accessed 12 February 2021.

https://doi.org/10.5771/9783748908043-499, am 26.04.2023, 13:36:57 
Commission will propose in 2021 and which should contribute to the achievement of the objectives of the new Soil Strategy and the restoration of degraded soils. ${ }^{31}$

In addition, the European Commission aims to enshrine the so-called 'no-debit rule' in EU law by incorporating land use into the EU's emission-reduction efforts. The actions of farmers to secure carbon stored in soils will thus contribute to achieving the EU's commitment under the Paris Agreement on climate change to reduce greenhouse gas emissions by at least $40 \%$ by 2030 compared to 1990 levels. ${ }^{32}$ This example is worthwhile viewing, as African countries have enormous opportunities to contribute to the global efforts in combatting climate change. However, most NDCs submitted by African countries do not (yet) truly reflect national needs and potential to fully contribute to global targets of achieving a low-carbon and climate-resilient pathway by 2050 .

Soil agronomy, circular bioeconomy and supply chain management

Driven by a global population projected to rise to over 10 billion people by 2050 (from 7.6 billion today) and an increase in the 'consuming class' with the purchasing power to demand more food per capita (including food with a higher environmental footprint), the world could require a doubling in agricultural production from 2005 levels in order to meet demand. Such a trajectory is unsustainable. ${ }^{33}$

A more circular bioeconomy should be based on healthy, biodiverse and resilient ecosystems that provide the basis of sustainable well-being for society at large. This can be achieved by means of functioning ecosystem services and sustainable management of biological resources, leading to the circular transformation in food, feed, energy and biomaterials within the ecological boundaries of the ecosystem that it relies on. ${ }^{34}$

An alignment of the food and agricultural sector with the SDGs and the Paris Climate Agreement can enhance the interplay between environmental, nutritional, social and governance-related factors that need to be tackled while examining how business indicators might be developed in support of greenhouse gas (GHGs) emissions reductions. ${ }^{35}$

The food and land-use system could significantly benefit from a fundamental shift towards productive and regenerative agriculture. Transforming agricultural landscapes and farming practices for both food and non-food agriculture through a combination

31 See https://ec.europa.eu/environment/news/commission-consults-new-eu-soil-strategy-202102-02_en, accessed 10 February 2021.

32 See https://ec.europa.eu/clima/policies/strategies/progress_en, accessed 10 February 2021.

33 World Economic Forum (2020).

34 Lawrence \& Reder (2019: 15).

35 Sachs et al. (2020). 
of traditional farming techniques, advanced precision technologies, and bio-based inputs can increase biodiversity, enrich soils, improve water management and enhance ecosystem services while improving yields. This transition, however, requires greater understanding and adoption of the appropriate agronomic solutions, including re-alignment of agricultural subsidies, while navigating trade-offs between improving yields and strengthening biodiversity outcomes. ${ }^{36}$

Long-term scenarios of adoption of agroecological approaches and provision of ecosystems services will help evaluate the benefits and potential trade-offs for society and provide desirable pathways for policy makers. Agriculture and conservation actors should seek consensus over indicators of sustainability and farmers should be supported to improve their performance against those indicators developing scientifically established agroecological approaches. ${ }^{37}$

In the context of end-use and market integration, this, inter alia, involves exploiting economies of scope across products, supply chains, land-use, transportation, city planning, and climate mitigation. ${ }^{38}$ It is, for instance, possible to design cities in a way that reduces the amount of soil lost. Designing greener cities with commercial areas scattered throughout the city avoids paving over large areas, shortens transport distances, and leaves room for open landscapes and gardens. ${ }^{39}$

Agricultural policy is influenced by more than just political forces. An understanding of food supply chains is important in the context of soil management practices. Improving soil management is important to the food and farming supply chain, increasing the performance of soil to produce higher yields that are more resilient to physical and financial shocks as well as the effects of climate change. The increased number of regulatory policies can be seen as the result of higher standards of living, which have boosted consumers' demand for safe and high-quality products, and of growing problems with water, air and soil pollution. Economic growth is a driver of poverty reduction but is also responsible for environmental destruction. In a world already confronted with climate change, diminishing exhaustible natural resources, and other threats to the environment, international trade contributes further to these harmful developments through the production of agricultural goods and global transportation as part of the supply chain. Moreover, "the modernisation of food supply chains, together with the implementation of agricultural policies focused more on the production of commodities than on food, has led to the marginalisation of local food systems, which is a trend that must be reversed". ${ }^{40}$

The value and protection of soil is interrelated with production and supply chain management. The environmental effects of production differ widely across countries owing to differences in climate, land availability, soil fertility, use of technology,

Larbodière (2020: 79)

38 Rogelj et al. (2018).

39 Heinrich Böll Foundation \& IASS (2015).

40 De Schutter (2014: para. 36). 
energy sources, laws and institutions, and other factors. ${ }^{41}$ This indicates that it can also be preferable to produce agricultural goods where this is most environmentally efficient. By promoting specialisation, competition, economies of scale, innovation and technology transfer at a global level, trade can both help to lower the production costs and help to achieve better environmental outcomes.

Supply chain management regulation is a relatively new attempt to address the economic and ethics problem of negative externalities in international trade by legal rule. It has become necessary because of a failure of the first-best solution of global rules and the failure of states to address the issue.

Subsidies, norms and standards in particular can block as well as encourage the desired transformation. Industry concentration or business strategies can be incompatible with the necessary rediversification of crop rotations and agricultural landscapes. Supply chain arrangements often lead to the concentration of value capture and decision-making power in the downstream part of the supply chain, preventing farmers from transitioning to more sustainable practices. ${ }^{42}$

Global financial flows should be increasingly redirected towards sustainable value chains and healthy landscapes, which would also benefit soil protection. Science can help to develop indicators and standards that can guide those investments towards more sustainable practices, products and processes along the food supply chain. ${ }^{43}$ An early identification of emerging risks lies at the heart of protecting public health and the environment and, by identifying such risks, for example in the food supply chain, can assure effective and timely measures to protect consumers.

As supply chain regulation also has inherent effects on international trade, it is crucial for its legality to also meet the requirement of world trade law. There is more leeway for individually agreed tariff preferences in compliance with regulations than at the World Trade Organisation (WTO) level. For this reason, various actors, including those from the supplier regions, should urgently be involved in the formulation of the details.

The African Continental Free Trade Agreement (AfCFTA) is expected to also develop and deepen supply chain trade across the African continent. The Agreement Establishing the African Continental Free Trade Agreement (AfCFTA) entered into force on 30 May 2019 and - after delays due to Covid-19 - was set to begin on 1 January 2021. The AfCFTA can develop new supply chain opportunities by eliminating existing obstacles, such as high tariffs on intermediate inputs to stimulate production of final goods and raise productivity. Moreover, the rules-of-origin ( $\mathrm{RoO})$ need to be harmonised and designed in a manner to make them easier to apply.

Through development policy measures more sustainability can be achieved by regulating supply chains to become flexible to react. In principle, the current direction of supply chains can be reversed in the future. Today's suppliers could become processors

41 UNEP \& WTO (2018)

42 Larbodière et al. (2020: 68).

43 Ibid.: 81. 
at the end of supply chains with greater added value - which could have positive development impacts for currently supplying developing countries. ${ }^{44}$

Agricultural commodities trade is subject to changes, reflecting the uneven and disproportionate impact of climate change on agricultural sectors across the globe. There is widespread agreement that, for instance coupled subsidy payments, export refunds, and direct market interventions have made a major contribution to increasing agricultural production in the EU and have led to the EU's increased export surplus. Low-priced food imports have weakened the agricultural sectors of African countries in the long-term and hindered the development of competitive agricultural production. However, the more targeted linking of agricultural subsidies to environmental and climate regulations increases the costs of agricultural production in the EU and could be expected to reduce the EU's production and export surpluses. This would create local agricultural investment incentives in Africa. ${ }^{45}$

The fact that the WTO Agreement on the Application of Sanitary and Phytosanitary Measures (SPS Agreement) makes reference to Codex food safety standards, means that the Codex Alimentarius for international food standards also has far reaching implications for international food trade. WTO members that wish to apply stricter food safety measures than those set by Codex may be required to justify these measures scientifically. The Codex standards are based on the assumptions and decisions of the Codex Alimentarius Commission, a joint body of the Food and Agriculture Organisation (FAO) and the World Health Organisation (WHO) of the United Nations and serve in many cases as a basis for national legislation. ${ }^{46}$

International food trade has existed for thousands of years but traditionally food was mainly produced, sold and consumed locally. Over the last century the amount of food traded internationally has grown exponentially, and a quantity and variety of food never before possible, with billions of tonnes of food produced, marketed and transported globally. ${ }^{47}$ By for instance moving food from surplus to deficit areas, trade can not only provide a mechanism to address production shortfalls due to extreme weather but can also contribute towards reducing greenhouse gas (GHG) emissions and adjusting agricultural production in a more efficient and local manner. This, in turn, could also be in the interest of soil protection.

44 Rudloff \& Wieck (2020).

45 Kornher \& von Braun (2020).

46 Cf. http://www.fao.org/fao-who-codexalimentarius/en/, accessed 10 February 2021.

47 Ibid. 
While the work to translate the Paris Agreement and the NDCs into concrete climate interventions in agriculture is in progress, a wide range of policy instruments is available, from investments in innovative technologies to subsidies that provide incentives to farmers to adopt climate-smart agricultural practices, and regulations to reduce emissions of agricultural activities to carbon taxes. ${ }^{48}$ Most of these policy instruments are covered by agreements under the WTO, which is the forum for governments where international trade agreements are negotiated.

\subsection{World Trade Organisation}

The World Trade Organisation (WTO) provides a system of trade rules covering goods, services and intellectual property, as well as a legal and institutional framework for the implementation and monitoring of these agreements, and a venue for settling disputes arising from the interpretation and application of WTO agreements. Administering WTO trade agreements, monitoring national trade policies, providing technical assistance and training for developing countries, and cooperating with other international organisations are further functions of the WTO. ${ }^{49}$

The WTO's founding and guiding principles remain the pursuit of open borders, the guarantee of the most-favoured-nation principle and non-discriminatory treatment by and among members, and a commitment to transparency in the conduct of its activities. The opening of national markets to international trade, with justifiable exceptions or with adequate flexibilities, can encourage and contribute to sustainable development, raise people's welfare, reduce poverty, and foster peace and stability. At the same time, the liberalisation of markets must be accompanied by sound domestic and international policies which contribute to economic growth and development according to each member's needs and aspirations. ${ }^{50}$

Although the WTO is primarily concerned with reducing trade barriers and eliminating discriminatory treatment in international trade, world trade law is increasingly framed by the concept of sustainable development. The agreement establishing the WTO (unlike the General Agreement on Tariffs and Trade (GATT)) has anchored the objective of sustainable development and the need to protect and preserve the environment within its Preamble:

Recognizing that their relations in the field of trade and economic endeavour should be conducted with a view to raising standards of living, ensuring full employment and a large and steadily growing volume of real income and effective demand, and expanding the production of and trade in goods and services, while allowing for the optimal use of the world's resources in accordance with the objective of sustainable development, seeking both to protect and preserve the

49 See Article III of the Agreement Establishing the WTO.

50 Ibid. 
environment and to enhance the means for doing so in a manner consistent with their respective needs and concerns at different levels of economic development.

Although this statement in the Preamble is more of a policy goal than a binding principle, it should have significant weight in decision-making and dispute resolution and can make an important difference to the agreement's operation in practice. Yet, the WTO is, of course, not an environmental protection agency. So far, its competence in the field of trade and environment is limited to trade policies and to the trade-related aspects of environmental policies that have a significant effect on trade. In addressing the link between trade and environment, the two fields should increasingly complement each other. ${ }^{51}$

How can the WTO trading system help with the implementation of the Paris Climate Agreement, mitigate climate change, enhance soil protection and contribute to food security $?^{52}$ The WTO has tremendous potential to contribute to decarbonisation and, relatedly, has significant potential to help mitigate climate change. ${ }^{53}$ This hypothesis raises the question: How can progressive trade liberalisation be reconciled with the protection of non-economic interests where the trading system can contribute to mitigating climate change, shifting from trade as a major cause of environmental harm to trade as a tool for environmental protection $?^{54}$ And what does this mean for the protection of soil and the promotion of food security in the context of climate change, which is likely to affect agricultural production more and more across various sectors?

\subsection{Trade in agriculture under the WTO}

In the decades following the Second World War, both the United States and nations of Western Europe provided generous subsidies to their agricultural producers and imposed both tariff and non-tariff import barriers to protect these producers from foreign competition.

\subsubsection{The 1947 General Agreement on Tariffs and Trade (GATT)}

The 1947 General Agreement on Tariffs and Trade (GATT) generally exempted agriculture from the GATT's trade liberalisation obligations: ${ }^{55}$

Trade in agriculture has been distorted by subsidies and protectionism to the detriment of both producers and consumers. Trade in agricultural products at the same time contributes to global

51 Ruppel (2018).

52 Leal-Arcas \& Morelli (2018: 32).

53 Ibid.: 6.

54 Ibid.: 29.

55 Gonzalez (2014). 
food security by helping countries to obtain food supplies from world markets. Agricultural imports can be risky if they crowd out more expensive local production. This can have negative income effects for producers and thereby continuously weaken local agriculture. In the case of acute supply bottlenecks, such effects can often only be quickly remedied by imports, provided that enough food is available on the world market at affordable prices. ${ }^{56}$

Since the start of the Brexit negotiations, the agri-food sector suffered under a lack of certainty regarding the future relationship between the European Union (EU) and the United Kingdom (UK). Existing supply chains and trade flows for agricultural goods and food products, within the EU but also with respect to imports from and export to third countries, suggest a significant challenge for farmers and food businesses in the $\mathrm{UK}$, in Ireland, across the EU and around the world. Issues of relevance range from market access to plant protection, food safety, and food and quality labelling. ${ }^{57}$

International trade of food commodities induces a virtual transfer of embodied land, carbon, and other land-based resources, while most of the environmental impacts of agricultural production remain in the producing countries the role of trade in food security is expected to increase due to climate change, population growth and changing diets. ${ }^{58}$ The causes of, and contributing factors to, global food insecurity are numerous and complex. It is clear, however, that the WTO and international trading rules play an important role in the pursuit of global food security. ${ }^{59}$

GATT Article XXI forms a controversial WTO provision recognising certain flexibilities for states in the international trading system, permitting ordinarily trade-restrictive measures for the purpose of national security. Article XXI(b)(iii) on "security exceptions" states that nothing in the GATT must be construed to prevent any WTO Member "from taking any action which it considers necessary for the protection of its essential security interests" in times of "emergency in international relations". This provision can justify certain trade restrictions introduced in pursuit of certain political objectives.

In 2019 in the case of Russia - Measures Concerning Traffic in Transit the WTO Dispute Settlement Panel found that "essential security interests" could be generally understood as referring to those interests relating to the quintessential functions of the state. The Panel observed that the specific interests at issue will depend on the particular situation and perceptions of the state in question and can be expected to vary with changing circumstances. For these reasons, the Panel held that it is left in general to every Member to define what it considers to be its essential security interests. ${ }^{60}$

According to Article XI of the GATT, supply risks explicitly justify otherwise prohibited trade restrictions and bans for food. Since trigger criteria and deadlines are not regulated, export bans are implemented rapidly, which in principle drives prices up 
and results in supply risks for other import-dependent countries. On the import side, protective tariffs can seal off sectors in particularly threatening situations, as is often the case for reasons of supply to stimulate production. In bilateral agreements, the weaker partners often condemn this protection option as too restrictive. At the same time, caution should be given against premature isolation, as it often makes sense to secure supplies through less expensive imports. In principle, the WTO complicates such incentives for specifications on production processes that do not lead to physical product differences, as is usually the case when considering sustainability. ${ }^{61}$

Article XI GATT has been violated in the context of a number of environmental disputes in which countries have imposed bans on the importation of certain products; it therefore has relevance for trade and environment discussions. Article XX grants general exceptions from the aforementioned GATT rules. Article XX(b) lists measures necessary to protect human, animal or plant life and health; Article $\mathrm{XX}(\mathrm{g})$ lists measures relating to the conservation of exhaustible natural resources. WTO members may be exempted from GATT rules in specific instances. However, measures must be necessary (necessity-test). If the conditions set by Article XX are fulfilled, they must still pass the test of the introductory clause (Chapeau) of Article XX. According to the Chapeau, measures may not be pronounced as arbitrary and unjustifiable discrimination between countries where the same conditions prevail, and they may not constitute a disguised restriction on international trade. GATT rules provide significant scope for members to adopt national environmental protection policies. ${ }^{62}$ GATT rules impose only one requirement in this respect - that of non-discrimination. WTO members are free to adopt national environmental protection policies provided that they do not discriminate between imported and domestically produced like products (NT principle), or between like products imported from different trading partners (MFN clause). Nondiscrimination is one of the main principles on which the multilateral trading system is founded. It secures predictable access to markets, protects the economically weak from the more powerful, and guarantees consumer choice. ${ }^{63}$

Certification and appropriate, non-deceptive labelling in line with WTO rules, in particular the Agreement on Technical Barriers to Trade (TBT), can enable consumers to make sustainable food choices avoiding unjustified barriers to trade. International food-safety as well as plant and animal health standards, based on the SPS Agreement, are essential for reaping the benefits of agricultural trade and for avoiding potential risks to human, animal and plant health, while unjustified sanitary and phytosanitary restrictions on food trade can exacerbate food insecurity. ${ }^{64}$

61 Rudloff \& Wieck (2020).

62 Ruppel (2018).

63 On the trade and environment negotiations see https://www.wto.org/english/tratop_e/envir_e/envir_negotiations_e.htm, accessed 10 February 2021.

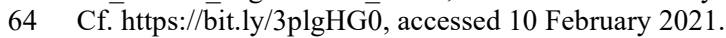


In 2011, the World Health Organization (WHO) reported that several European countries have experienced outbreaks caused by a dangerous strain of Escherichia coli (E. coli) bacteria, while some countries have also reported deaths related to the outbreaks. These E. coli are strains of the bacterium Escherichia coli that produce either Shiga or Shiga-like toxin while only a minority of these cause illness in humans. The ones that do are collectively known as enterohemorrhagic E. coli (EHEC) and are major causes of foodborne illness. Responses then have involved actions that implement and affect international legal regimes on public health and international trade imposing restrictions on international trade in terms of the Agreement on the Application of Sanitary and Phytosanitary Measures (SPS Agreement). ${ }^{65}$ Following the detection of EHEC bacteria on Spanish cucumbers on 26 May 2011 (which, however, later proved to be of a different type than the E. coli associated with the outbreak), the competent ministries in various German federal states adopted regulations requiring traders to provide proof of safety for Spanish cucumbers, which was tantamount to a de facto import ban, leading the Spanish government to assert that it would seek compensation for its farmers, who lost sales costing millions of euros. On 1 June 2011, the EU Commission removed the warning label on Spanish cucumbers from the European rapid alert system, citing the latest investigation results. German courts then had to decide on the compensation for the damage suffered by Spanish cucumber suppliers. In turn, outside the EU, Russia imposed an import ban on 2 June 2011, on raw vegetables from all EU countries, prompting complaints from EU members that such a ban was not justified and was disproportionate. The EHEC outbreaks have triggered various trade responses internationally, under EU law and the SPS Agreement. Ultimately, they also underscored a problem with international legal obligations under the WHO and WTO regimes that seek to regulate trade-related responses to disease outbreaks. ${ }^{66}$

Article XX of the GATT 1994 states that measures "necessary to protect human, animal or plant life or health" (b) and those "relating to the conservation of exhaustible natural resources $[\ldots]$ ". (g) can be interpreted as a legally accepted exception. While this could be most relevant for the protection of soil, a typical measure that can fall under this exception may be requiring export countries to comply with certain policies prescribed by the importing country. ${ }^{67}$

Further exceptions in accordance with Article XX of the GATT could possibly also be used to justify border carbon adjustment (BCA) measures as a tool for addressing carbon leakage. Such measures could, for instance, be the inclusion of certain imported goods in a Carbon Emissions Trading Scheme (ETS), a customs duty, or a border tax.

To adhere to WTO principles of non-discrimination, countries cannot ask for more or different compliance from importers than they ask of their own firms producing comparable products.

66 Ibid.

67 Van den Bossche \& Zdouc (2017). 
That means that only price-based climate policies can be associated with a price at the border. A domestic carbon tax can be complemented by a border tax. ${ }^{68}$

The Paris Agreement does not explicitly state but implies counteracting like products and services with a higher footprint, which can take place in a number of different ways, and not necessarily through discrimination against only foreign goods (MFN/NT) ${ }^{69}$ The Paris Agreement does not prescribe border carbon adjustment measures. Whether a carbon tax yields a better result for global food security than carbon sequestration remains open for discussion beyond the scope of this article. Yet, the rapidly increasing food import volumes or price decreases may legitimise safeguarding action by countries which have had to transform their non-tariff barriers (NTBs) into tariffs. Basically, however, rules and limits apply to four categories of protection and support policies. Border protection should be limited to tariffs. The maximum rates (bound/scheduled) should not be increased without compensation as per Article XXVIII of the GATT. Import quotas are prohibited under Article XI of the GATT. A time-limited border protection is available against imports threatening or jeopardising local production, which are generally available safeguards under Article XIX of the GATT. ${ }^{70}$ In addition, in Article XXIV(5) of the GATT, WTO members may exclude customs unions and bilateral or regional free-trade areas from compliance with WTO disciplines in certain circumstances. These regional agreements are important, as they establish disciplines which might affect both the adoption of domestic and international carbon rules and measures to promote sustainable development and environmental cooperation. ${ }^{71}$

\subsubsection{The WTO agreements on agriculture, subsidies and countervailing measures}

The Agreement on Agriculture (AoA) entered into force at the time of the inception of the WTO on 1 January 1995. In principle, all WTO rules on trade in goods apply to agriculture. These rules include, inter alia, the GATT and pacts such as those dealing with sanitary and phytosanitary measures, customs valuation, import licensing, preshipment inspection, safeguarding measures, subsidies in general, and various standards, regulations and labelling requirements that imports have to meet (known as "technical barriers to trade"). The AoA was negotiated in the Uruguay Round (1986-1994) and was a significant step towards fairer competition and a less distorted sector. WTO member governments agreed to improve market access and reduce trade-distorting subsidies in agriculture. The AoA seeks to reform trade in agricultural products and provides the basis for market-oriented policies. In its Preamble, the Agreement

68 Droege \& Fischer (2020).

69 Häberli (2018: 20).

70 Ibid.: 8 .

71 See with further references Gehring \& Hepburn (2013). 
reiterates the commitment of members to reform agriculture in a manner which protects the environment. Under the Agreement, domestic support measures with minimal impact on trade (known as green box policies) are excluded from reduction commitments (contained in Annex 2 of the Agreement). ${ }^{72}$

The AoA primarily covers three aspects which need to be adapted to improve international agricultural trade, namely market access, export competition and domestic support. Market access is set out in Articles 4 and 5 of the AoA, and requires member states to convert their non-tariff barriers into tariffs and then to reduce those tariffs to improve agricultural trade market transparency and to strengthen the connection between domestic and international agricultural markets. The AoA also highlights the need for stricter regulation of domestic support measures under Articles 3,6 and 7 to avoid their use for protectionist strategies which promote unfair competition, and categorises domestic agricultural support measures into 3 boxes according to the level of their trade-distorting effect, namely amber box, blue box and green box measures. Exemptions for reductions in support measures include green box subsidies which are considered minimal or non-trade distorting and include support for public stockholding for food security purposes and domestic food aid, as well as development measures which assist support of agricultural and rural development objectives. Export competition, as set out in articles 9 and 10 of the Agreement on Agriculture, required member states to make reduction commitments on their export subsidies. Article 20 recognises the importance of taking into account non-trade concerns and special and differential treatment for developing country members, resulting in many developing countries, through negotiating groups bringing forward proposed amendments to the AoA on the elimination of export subsidies, the use of public stockholding in the context of food security purposes and trade remedies such as special safeguard mechanisms.

The AoA in Article 21(1) stipulates that the GATT and all other WTO agreements on trade in goods (officially Annex 1A of the Marrakesh Agreement establishing the WTO) apply but if there is a conflict, then the rules in the Agriculture Agreement prevail. ${ }^{73}$ While the "AoA professed to ameliorate the double standards in global agricultural trade", it has been said that it $-{ }^{74}$

was riddled with ambiguities that enabled wealthy countries to continue to subsidize their agricultural producers while requiring market openness in developing countries. Since most developing countries had already liberalised their markets pursuant to structural adjustment programs, the impact of the AoA was to preclude these countries from adopting these subsidies in the future beyond de minimis levels. Agricultural subsidies in the United States and European Union, however, actually increased in the aftermath of the AoA. 
In terms of agricultural product subsidies there is no outright prohibition, but because they are considered to distort trade, they are limited for all WTO members. The conditions for unlimited governmental programmes are narrowly defined. The Developing Country Green Box (Article 6(2) AoA) allows, for instance, certain credit schemes and subsidies, for example for irrigation construction, and even for the running costs of low-income and resource-poor producers. Article 6(2) provides in relevant parts that measures which are "an integral part of the development programmes of developing countries [...] shall be exempt from domestic support reduction commitments that would otherwise be applicable to such measures". These are "investment subsidies which are generally available to agriculture in developing country Members and agricultural input subsidies generally available to low-income or resource-poor producers in developing country Members". ${ }^{75}$

Nevertheless, there is still a need to update global trade rules to reflect market and policy shifts that have occurred in recent years and to address contemporary agricultural and food challenges in reducing trade-distorting agricultural support of the past. ${ }^{76}$ This does not come as a surprise, as the AoA has given rise to a relatively large number of disputes reflecting the fact that agriculture is a sensitive sector in many member countries. In its 2019 recent panel report DS511 on China - Domestic Support for Agricultural Producers the DSB found that China was not in compliance with its domestic support commitments pursuant to Articles 3(2) and 6(3) of the Agreement on Agriculture after the United States contended that China has provided market price support to its agricultural producers of wheat and rice in excess of its commitments under the AoA. ${ }^{77}$

The agriculture, forestry, and other land use (AFOLU) sector is an important sector that services national food requirements and export earnings for many developing countries around the world. It is unique in the sense that it is the only sector within which both sources and sinks for greenhouse gases can be found. AFOLU plays a central role in food security, sustainable development and climate change mitigation and adaptation and could also be considered as a valid motive under Article 6(2) AoA through measures that do not distort trade. Effective climate-smart support to farmers can also improve the comparative advantage of agriculture in countries that will be negatively affected by changing climate, allowing them to become competitive and achieve a better balance in export and import performance. ${ }^{78}$

Further relevant provisions for trade in agricultural products are found in the WTO Agreement on Subsidies and Countervailing Measures (SCM). SCM exerts discipline over the use of subsidies and regulates the actions that countries can take to counter

75 Häberli (2018: 9).

76 Cf. https://bit.ly/3qfnlic, accessed 10 February 2021.

77 Cf. https://bit.ly/3qeGiS7, accessed 10 February 2021.

78 Deutz et al. (2020). 
the effects of subsidies. Under the agreement, a country may use the WTO's disputesettlement procedure to seek the withdrawal of the subsidy or the removal of its adverse effects. Alternatively, a country can launch its own investigation and ultimately charge extra duty (countervailing duty) on subsidised imports found to be detrimental to domestic producers. ${ }^{79}$ In line with Article 13 AoA, the SCM agreement now also applies to agricultural export (and import displacement) measures. Although export subsidies - a long-term concern of many competitive agricultural product exporters were finally prohibited in 2015 , there still is no agreement on the implementation details (eg schedule changes) nor on the rules tightening mandated for all export competition measures under the Doha Development Agenda (DDA). This failure is also reflected in the stalling reform process under Article 20 of the AoA to agree on additional disciplines making trade patterns more sustainable, more resilient under a climate change perspective.

The key for an economic impact assessment of agricultural subsidies in a climate perspective would probably be the contribution of a differentiating subsidy under the Paris Agreement. Here again, not all countries are equal. Some temperate climate countries may actually benefit from global warming, with little or no justification for a subsidy. For countries located closer to the Equator, adaptation subsidies and Official Development Assistance (ODA) might find economic justification especially for farmers without meaningful support from their governments. ${ }^{80}$

This could contribute to global efforts to control atmospheric greenhouse gas concentrations, foster AFOLU-related mitigation pathways and at the same time lead to improved soil conditions. In this regard, trade could become more central in climate change mitigation efforts and this would also benefit soil protection. If trade could provide the necessary signals to farmers to produce low carbon footprint products, emissions could be reduced globally. In practice, this would necessitate the imposition of a carbon tax (or an equivalent mitigation measure) on agricultural products domestically, combined with a corresponding tariff adjustment at the border to discriminate against high carbon footprint imports.

WTO provisions offer flexibility for waivers or exemptions from complying with the non-discrimination principle. While sufficient space for policy discussions needs to be pursued at the intersection of the WTO and the Paris Agreement, the principle of differentiated responsibilities, respective capabilities, and the special and differential treatment of developing countries remain ever relevant when discussing and implementing transformative policies for climate change adaptation and mitigation to make agriculture meet contemporary challenges. ${ }^{81}$

Moreover, regional trade agreements such as the AfCFTA also have high potential to boost intra-African trade and to restore certain imbalances in the world agricultural trade markets, which - for instance - also provides an opportunity to revisit EU-Africa

79 See http://www.wto.org/english/tratop_e/scm_e/scm_e.htm, accessed 10 November 2017.

80 Leal-Arcas (2018: 25).

81 FAO (2018b: 97). 
trade policy relations in the fields of food and agriculture, where greater emphasis should be laid on African development, including environmental, climate, health and distributional aspects. ${ }^{82}$ This was explicitly reflected in 2014 Malabo Declaration of the African Union on Accelerated Agricultural Growth and Transformation for Shared Prosperity and Improved Livelihoods where it was declared to boost intra-African trade in agricultural commodities and services, especially through the establishment of the AfCFTA and to enhance resilience of livelihoods and production systems to climate variability. ${ }^{83}$

\section{Conclusion}

The fact, that the Norwegian Nobel Committee has decided to award the 2020 Nobel Peace Prize to the World Food Programme (WFP) for its efforts to combat hunger is a clear reflection of the growing significance of food security in our time. The WFP is the world's largest humanitarian organisation addressing hunger and promoting food security and the primary instrument of the United Nations for realising this goal. The Norwegian Nobel Committee emphasised that providing assistance to increase food security not only prevents hunger but can also help to improve prospects for stability and peace in the world. ${ }^{84}$

Ending hunger and achieving food security is at the heart of the SDGs. At the same time, climate change is affecting agriculture and food security and will make the challenge even more difficult. In fact, food insecurity and climate change already undermine basic human rights of entire populations - especially in Africa.

Food security as a primary justice concern connected with climate change must therefore also be viewed in the context of food production and distribution, where producers and consumers are located on different continents. In fact, a better understanding of food security must go beyond a developmental or humanitarian understanding thereof, it must even include linkages with geopolitics. ${ }^{85}$

As the historical impact of global supply chains on nature has been largely negative, characterised by unsustainable practices in agriculture and other sectors. What must, however, be prevented is an increasing securitisation of trade where countries put up trade barriers on just about everything under the pretext of security. ${ }^{86}$ Instead of

82 Kornher \& von Braun (2020: 5).

83 Malabo Declaration on Accelerated Agricultural Growth and Transformation for Shared Prosperity and Improved Livelihoods Malabo, Equatorial Guinea, 26 June 2014, https://au.int/sites/default/files/documents/31247-doc-malabo_declaration_2014_11_26.pdf, accessed 25 November 2020.

84 See https://www.nobelprize.org/prizes/peace/2020/press-release/, accessed 10 February 2021.

85 Zhou et al. (2020).

86 Narlikar (2020). 
disrupting global value chains, a shift toward more responsible supply chain management practices offers an opportunity to avoid harm and even positively impact nature..$^{87}$

Whereas misguided aid, trade and development policies, as well as large-scale land acquisitions that benefit wealthy nations and transnational corporations are often conducted at the expense of the poor, ${ }^{88}$ they are also most vulnerable and threatened by climate change, which depresses food production and increases food prices. ${ }^{89}$

International trade, while essential for food security, also creates vulnerabilities through supply disruptions, growing unilateralism and competition over agricultural resources that can be both a cause and a consequence of geopolitical rivalry. ${ }^{90}$ The WTO is a crucial institution for the governance of international trade, yet it has been characterised by frequent deadlocks in the past and has suffered from credibility loss due to the persistent failure of the Doha Development Agenda. The WTO is now subject to ongoing trade war dynamics and a dysfunctional appellate body, all of which further exacerbates the need for reforms. ${ }^{91}$

Moreover, some countries have been hoarding food items to ensure supplies for their population in light of the Covid-19 pandemic. Such grain exporters, including Russia, the Ukraine and Kazakhstan, have been said to take a nationalist turn by restricting or planning to restrict exports to ensure enough supplies for their own populations. The is an alarming example on how food availability can easily be threatened in a trade system that encourages import dependence and export-oriented agriculture, but cannot require countries to export food, which could be detrimental to countries that depend on imported food. ${ }^{92}$ Trade wars are a huge threat to food security. ${ }^{93}$ Further examples are Russia's ban on Western food imports since 2014 and the ongoing trade war between China and the USA that began in 2018 disrupting normal agricultural flows. These geopolitical frictions hamper reform consensus to revive multilateral institutions, including the WTO,${ }^{94}$ which should be empowered beyond the trade effects of trade. ${ }^{95}$

Countries should increase efforts through the international architecture, specifically the WTO, to develop green trade agreements that facilitate and incentivise increased trade in commodities produced without conversion of natural habitats. While subsidies are, for the most part, deployed within the country granting the subsidies and can only be reformed through the actions of domestic governments, reforming harmful

87 Deutz et al. (2020: 66)

88 Gonzales (2014: 104).

89 Niang et al. (2014: 1218).

90 Zhou et al. (2020).

91 Narlikar (2020).

92 Pandey (2020).

93 Cf. https://unctad.org/news/trade-wars-are-huge-threats-food-security, accessed 10 February 2021).

94 Zhou et al. (2020).

95 Messenger (2017). 
subsidies still requires an international effort. International organisations can facilitate changing the status quo on subsidies reform and encourage governments to cooperate on ways to implement change. ${ }^{96}$

While every country must have the right to develop its own agricultural model to feed its population, respect for the needs of other countries and international obligations remains key. Policies must therefore assure that trade can meet global challenges, facilitates the sustainable and efficient use of land, protects biodiversity and prevents overexploitation and degradation of land and natural resources. In particular, nationally appropriate measures to conserve natural resources and combat climate change that are respectful of international commitments related to sustainable development, e.g., the Paris Agreement on Climate Change, the Rio Declaration on Environment and Development and the Convention on Biological Diversity.

WTO reform to better accommodate climate change measures is an increasingly urgent issue. Such reform could entail legal changes, namely amending the WTO agreements to accommodate climate change measures; introducing a waiver that temporarily relieves WTO members from their legal obligations under the WTO agreements when pursuing climate action; adopting an authoritative interpretation clarifying the scope of WTO rules in relation to climate policies; and introducing a time-limited peace clause pursuant to which WTO members will not challenge the climate policies of other members. Such changes would, however, involve complex political processes that - for a variety of reasons - would be difficult to implement in practice.

In the meantime, existing flexibilities under current WTO law should be utilised to advance climate action, while it is not unlikely that conflicts between the trade and climate regimes will sooner or later surface in the WTO's dispute settlement system. It has been rightfully stated that international courts and tribunals must become the new environmental sentinels in international law. ${ }^{97}$ In the interest of global soil protection and for the sake of sustainable food security, the challenge will be to bridge the gap where measures claiming to implement the Paris mitigation commitments collide with present trade rules. This will require commitment to overcome substantial barriers at various institutional (and conceptual) levels as well as adequate and corresponding regulatory frameworks. With more ambitious NDCs expected in the future, countries can take trade-related climate measures that are likely to assume increasing importance. ${ }^{98}$

The fact is that the climate protection goals of the Paris Agreement can only be reached if, in addition to the decarbonisation of the global economy, more areas of land are used to extract carbon dioxide $\left(\mathrm{CO}_{2}\right)$ from the atmosphere. ${ }^{99}$ And soil as a 
natural system is essentially a capital stock (similar to financial, built, and human capital) that provides a flow of services to people. These 'ecosystem services', which include fertile soil must be considered in the context of regenerative or conservation agriculture, yielding a public good. In this light, greater efforts are needed to combine economic and environmental performance in determining soil as a natural capital and a valuable asset that needs a price tag (despite the fact that it is actually priceless). Soil organic carbon is a fundamental ecosystem health indicator. ${ }^{100}$ Moreover, when it comes to the protection of soil, the right to private property as a secondary natural right needs to be linked to the principle of the universal destination of the earth's goods, which may require higher consideration in the workings of any future society. ${ }^{101}$

Policymakers who turn to science will discover that it can guide the formulation of laws that actually bring about efficient change consistent with the laws of nature, ${ }^{102}$ towards a transformational shift in the way markets, and the discipline of economics more broadly, value nature. The role of science has also become more important in determining parties' rights and in the adjudication of international trade disputes. Science can assist in the process of risk identification and more importantly, risk assessment and the management of such an identified risk. ${ }^{103}$ In fact, certain vulnerability situations may even lead to a new realisation that global stability and systemic relevance (e.g., food supply) are not only a matter of economic optimisation. ${ }^{104}$

Unlike the climate, soil protection has so far too often been neglected in international agreements. Despite this oversight, the climate goals cannot be reached without soil protection and conservation. The same applies when it comes to ensuring the right to food. In fact, soil protection should perhaps be viewed in light of the public trust doctrine, which has its origins in the Roman law property concept of res communis. ${ }^{105}$ These are things which, by their nature, are part of the commons that all humankind has a right or at least a common interest in the protection thereof. Notwithstanding this, the legalisation of guiding principles and cooperation between sectors and institutions addressing soil holds significant potential for improving soil governance and thus enhancing resilience against food insecurity, which must be pursued in a complementary manner in order to be able to counter soil degradation and mitigate climate change. ${ }^{106}$

100 Chotte et al. (2019).

101 Pope Francis (2020).

102 Laitos (2019).

103 This is prevalent in both the WTO Appellate Body Report, European Communities - Measures Concerning Meat and Meat Products (EC-Hormones), WT/DS48/AB/R, 16 January 1998 and WTO Panel Report, European Communities - Measures Affecting the Approval and Marketing of Biotech Products (EC - Biotech Products), WT/DS291/R, 29 September 2006. Science has become a major role in determination of WTO cases. Cf. Du (2018).

104 Ginzky et al. (2020).

105 Preston (2018).

106 Ruppel (2013). 
Lastly, due to the vulnerability of African countries there is an increased need for boosting intra-African trade, particularly in agricultural products, to address issues of poverty and hunger, and to guard against food insecurity as a result of competition in trade from the international community, as well as decreased agricultural production as a result of the increasing impact of environmental threats and the degradation of soil. In this light, any transition to climate neutrality and decarbonisation should be guided by the leitmotiv to place soil protection and sustainable food security at the centre of economic agricultural trade policy.

\section{References}

Bodle, R., H. Stockhaus, F. Wolff, C.-S. Scherf, \& S. Oberthür, 2020, Improving international soil governance - Analysis and recommendations. Dessau-Roßlau: German Environment Agency.

Chotte, J.L., E. Aynekulu, A. Cowie, E. Campbell, P. Vlek, R. Lal, M. Kapović-Solomun, G. von Maltitz, G. Kust, N. Barger, R. Vargas \& S. Gastrow, 2019, Realising the carbon benefits of sustainable land management practices: Guidelines for estimation of soil organic carbon in the context of land degradation neutrality planning and monitoring. A report of the science-policy interface. Bonn: UNCCD.

De Schutter, O., 2014, The transformative potential of the right to food. 24 January 2014, United Nations General Assembly, A/HRC/25/57, Human Rights Council, twenty-fifth session, Agenda item 3, Promotion and protection of all human rights, civil, political, economic, social and cultural rights, including the right to development, at http://www.srfood.org/images/stories/pdf/officialreports/20140310_finalreport_en.pdf, accessed 12 January 2021.

Desai, B.H. \& B.K. Sidhu, 2020, "International courts and tribunals - The new environmental sentinels in International Law”. Environmental Policy and Law 50, 17.

Deutz, A., G.M. Heal, R. Niu, E. Swanson, T. Townshend, L. Zhu, A. Delmar, A. Meghji, S.A. Sethi, \& J. Tobin de la Puente, 2020, Financing nature: Closing the global biodiversity financing gap. Chicago: The Paulson Institute, The Nature Conservancy, and the Cornell Atkinson Center for Sustainability.

Droege, S. \& C. Fischer, 2020, "Pricing carbon at the border: Key questions for the EU". ifo DICE Report 18,30 .

Du, M., 2018, "Re-conceptualizing the role of science in international trade disputes". Journal of World Trade 52 (5), 697.

European Commission, 2020, European Commission Roadmap: New soil strategy - healthy soil for a healthy life. Ref. Ares (2020) 6391319 - 05/11/2020, at https://ec.europa.eu/info/law/better-regulation/have-your-say/initiatives/12634-New-EU-Soil-Strategy-healthy-soil-for-a-healthy-life, accessed 12 November 2020.

FAO / Food and Agriculture Organization of the United Nations, 2018a, Right to adequate food in constitutions. Legal brief for Parliamentarians in Africa, No. 1. Rome: FAO.

FAO / Food and Agriculture Organization of the United Nations, 2018b, The state of agricultural commodity markets 2018. Agricultural trade, climate change and food security. Rome: FAO.

FAO / Food and Agriculture Organization of the United Nations, 2020a, Legislative approaches to sustainable agriculture and natural resources governance. FAO Legislative Study No. 114. Rome: FAO, at https://www.unenvironment.org/resources/publication/legislative-approachessustainable-agriculture-and-natural-resources, accessed 12 January 2021. 
FAO / Food and Agriculture Organization of the United Nations, 2020b, Climate change: Unpacking the burden on food safety. Food safety and quality series No. 8. Rome: FAO, at http://www.fao.org/3/ca8185en/CA8185EN.pdf, accessed 12 November 2020.

Fidler, D.P., 2011, "International Law and the E. coli outbreaks in Europe". Insights 15 (14), American Society of International Law (ASIL), at https://www.asil.org/insights/volume/15/issue/14/international-law-and-e-coli-outbreaks-europe, accessed 12 January 2021.

Fratini Vergano, European Lawyers, 2018, Trade Perspectives, Issue No. 18 of 5 October 2018, at http://www.fratinivergano.eu/static/upload/1/1/18.10_.05_TP_Issue_18-2018_.pdf, accessed 12 January 2021.

Geden, O. \& F. Schenuit, F, 2020, Unconventional mitigation carbon dioxide removal as a new approach in EU climate policy. SWP Research Paper No. 8. Berlin: German Institute for International and Security Affairs.

Gehring, M.W. \& J. Hepburn, 2013, "Climate, trade and investment law in the global green economy". In: Ruppel, O.C., C. Roschmann \& K. Ruppel-Schlichting (eds), 2013, Climate change: International Law and Global Governance - Volume I: Legal responses and global responsibility. BadenBaden: Nomos.

Ginzky, H., Löwe, C. and Neßhöver, C. 2020. "Lessons from the Corona Crisis: New Guiding Principles Required for Environmental and Sustainability Policy? - A Discussion Paper”. German Environment Agency, at https://bit.ly/378d2oC, accessed 30 October 2020.

Gonzalez, C.G. 2014. "World poverty and food insecurity". Pennsylvania State Journal of Law and International Affairs 3 (2), 100.

Häberli, C., 2018, Potential conflicts between agricultural trade rules and climate change treaty commitments. The state of agricultural commodity markets (SOCO) 2018. Background Paper. Rome: FAO.

Heinrich Böll Foundation \& IASS / Institute for Advanced Sustainability Studies. 2015. Soil Atlas 2015, Facts and Figures about Earth, Land and Fields. Berlin: Heinrich Böll Foundation and the Institute for Advanced Sustainability Studies, at https://www.boell.de/sites/default/ files/soilatlas2015_ii.pdf, accessed 10 February 2021.

Kasturi, D., H. van Asselt, S. Droege \& M. Mehling, 2018, Making the international trade system work for climate change: Assessing the options. London: Climate Strategies.

Kasturi, D., H. van Asselt, S. Droege \& M. Mehling, 2019, "Towards a trade regime that works for the Paris Agreement”. Economic and Political Weekly December 21, 25.

Kornher, L. \& J. von Braun, 2020, EU common agricultural policy - Impacts on trade with Africa and African agricultural development. ZEF Discussion Papers on Development Policy No. 294. Bonn: Center for Development Research.

Laitos, J.G., 2019, "How science has influenced, but should now determine, environmental policy". William and Mary Environmental Law and Policy Review 43, 759.

Larbodière, L., J. Davies, R. Schmidt, C. Magero, A. Vidal, A. Schnell, P. Bucher, S. Maginnis, N. Cox, O. Hasinger, P.C. Abhilash, N. Conner, V. Westerburg \& L. Costa, 2020, Common Ground: Restoring land health for sustainable agriculture. Gland: IUCN.

Lawrence, P. \& M. Reder, 2019, "Equity and the Paris Agreement: Legal and philosophical perspectives". Journal for Environmental Law 31 (3), 511.

Leal-Arcas, R. \& A. Morelli, 2018, "The resilience of the Paris Agreement: Negotiating and implementing the climate regime". The Georgetown Environmental Law Review 31 (1), 1.

Messenger, G., 2017, "Substantial development and the commodities challenge: The eventual greening of the World Trade Organisation". Trade Law and Development 54, 54. 
Narlikar, A., 2020, "Reforming the World Trade Organization". Heinrich Böll Stiftung, 17 January 2020, at https://www.boell.de/en/2020/01/17/reforming-world-trade-organization, accessed 12 January 2021.

Niang, I., O.C. Ruppel, M.A. Abdrabo, A. Essel, C. Lennard, J. Padgham \& P. Urquhart, 2014, “Africa". In: Climate change 2014: Impacts, adaptation, and vulnerability. Part B: Regional aspects. Contribution of Working Group II to the Fifth Assessment Report of the Intergovernmental Panel on Climate Change. Cambridge: Cambridge University Press.

Palahí, M., M. Pantsar, R. Costanza, I. Kubiszewski, J. Potočnik, M. Stuchtey, R. Nasi, H. Lovins, E. Giovannini, L. Fioramonti, S. Dixson-Declève, J. McGlade, K. Pickett, R. Wilkinson, J. Holmgren, K. Trebeck, S. Wallis, M. Ramage, G. Berndes, F.K. Akinnifesi, K.V. Ragnarsdóttir, B. Muys, G. Safonov, A.D. Nobre, D. Ibañez, A. Wijkman, J. Snape \& L. Bas, 2020, Investing in nature as the true engine of our economy: A 10-point action plan for a circular bioeconomy of wellbeing. Knowledge to Action 02. Joensuu: European Forest Institute.

Pandey, A. 2020. "Will Coronavirus spark a wave of food nationalism?", at https://bit.ly/3c94XTH, accessed 12 January 2021.

Peters, G. P., J.C. Minx, C.L. Weber \& O. Edenhofer, 2011, "Growth in emissions transfers via international trade from 1990 to 2008". Proceedings of the National Academies of Science 108 (21), 8903.

Pope Francis, 2020, Fratelli Tutti. Encyclical Letter of the Holy Father Francis on fraternity and social friendship, at http://www.vatican.va/content/francesco/en/encyclicals/documents/papa-francesco_20201003_enciclica-fratelli-tutti.html, accessed 12 January 2021.

Preston, B.J. 2018. "The evolving role of environmental rights in climate change litigation". Chinese Journal of Environmental Law 2, 131.

Rogelj, J., D. Shindell, K. Jiang, S. Fifita, P. Forster, V. Ginzburg, C. Handa, H. Kheshgi, S. Kobayashi, E. Kriegler, L. Mundaca, R. Séférian \& M.V. Vilariño, 2018, "Mitigation pathways compatible with $1.5^{\circ} \mathrm{C}$ in the context of sustainable development". In: IPCC, Global warming of $1.5^{\circ} \mathrm{C}$. An IPCC Special Report on the impacts of global warming of $1.5^{\circ} \mathrm{C}$ above pre-industrial levels and related global greenhouse gas emission pathways, in the context of strengthening the global response to the threat of climate change, sustainable development, and efforts to eradicate poverty. Cambridge: Cambridge University Press.

Rudloff, B. \& C. Wieck, 2020, "Nachhaltige Lieferketten im Agrarsektor: Wert schöpfen statt Zuliefern. Unternehmerpflichten politikfeldübergreifend in eine EU-Strategie einbinden". SWP-Aktuell 2020/A 70, September 2020.

Ruppel, O.C., 2013, "Intersections of law and cooperative global climate governance - challenges in the anthropocene". In: Ruppel, O.C., C. Roschmann \& K. Ruppel-Schlichting, (eds), Climate change: International Law and global governance Volume I: Legal responses and global responsibility. Baden-Baden: Nomos.

Ruppel, O.C., 2018, "International trade, environment and sustainable development". In: Ruppel, O.C. \& E.D. Kam Yogo, (eds) Environmental law and policy in Cameroon - Towards making Africa the tree of life. Law and Constitution in Africa, Bd. 37. Baden-Baden: Nomos.

Sachs J., M. Al Khatib, M. Antonelli, K.Y. Cordes, S. Cresti, G. Espinosa, C. Ocampo-Maya, Riccaboni, A. Rossi, L.E. Sachs, G. Schmidt-Traub, E. Sofra \& C. Tozzi, 2020, Fixing the business of food. How to align the agrifood sector with the SDGs. Parma: Barilla Foundation, at https://www.fixing-food.com/wp-content/uploads/2020/09/Executive_Summary_2020.pdf, accessed 12 January 2021.

Stewart, T.P. \& S. Manaker Bell, 2015, "Global hunger and the World Trade Organization: How the international trade rules address food security". Pennsylvania State Journal of Law and International Affairs 3 (2), 113. 
Tänzler, D., J. Groß, L. Li, C. Warnecke, M.J. Kurdziel, R. Tewari, M. Cames, \& S. Healy, 2019, Analysing the interactions between new market mechanisms and emissions trading schemes: Opportunities and prospects for countries to use Article 6 of the Paris Agreement. Dessau-Roßlau: German Environment Agency.

UNEP / United Nations Environment Programme \& WTO / World Trade Organization, 2018, Making trade work for the environment, prosperity and resilience. Nairobi: UNEP.

Van den Bossche, P. \& W. Zdouc, 2017, The law and policy of the World Trade Organization. 3rd edition. Cambridge: Cambridge University Press.

WBGU / German Advisory Council on Global Change, 2020, Rethinking land in the Anthropocene: From separation to integration. Berlin: WBGU.

World Economic Forum, 2020, The Future of Nature and Business. Geneva: World Economic Forum, at http://www3.weforum.org/docs/WEF_The_Future_Of_Nature_And_Business_2020.pdf, accessed 12 January 2021.

WTO / World Trade Organization, 2015, The WTO Agreements Series: Agriculture, at https://bit.ly/3tIBrd1, accessed 12 January 2021.

Zahar, A., 2020, "Collective obligation and individual ambition in the Paris Agreement". Transnational Environmental Law 9 (1), 165.

Zhou, J., L.M. Dellmuth, K.M. Adams, T.S. Neset \& N. von Uexkull, 2020, The geopolitics of food security: Barriers to the sustainable development goal of zero hunger. Insights on Peace and Security, No. 11. Stockholm: Stockholm International Peace Research Institute (SIPRI). 